Rev. Bras. Saúde Prod. Anim., Salvador, v.16, n.2, p.387-396 abr./jun.., 2015 http://www.rbspa.ufba.br ISSN 15199940

\title{
Probiotics: viable and inactivated cells on the performance, microflora and blood parameters of piglets
}

\author{
Probióticos: células viáveis e inativadas no desempenho, microbiota e parâmetros \\ sanguíneos em leitões
}

\author{
BUSANELLO, Marli ${ }^{1 *}$; POZZA; Magali Soares dos Santos²; POZZA, Paulo Cesar ${ }^{2}$; \\ NUNES, Ricardo Vianna ${ }^{3}$; CHAMBO, Ana Paula Sartório ${ }^{2}$; ECKSTEIN, Ilton Isandro ${ }^{4}$
}

\author{
${ }^{1}$ Universidade Estadual de Londrina, Centro de Ciências Agrárias, Programa de Pós-Graduação em \\ Ciência de Alimentos, Londrina, Paraná, Brasil. \\ ${ }^{2}$ Universidade Estadual de Maringá, Centro de Ciências Agrárias, Departamento de Zootecnia, Maringá, \\ Paraná, Brasil. \\ ${ }^{3}$ Universidade Estadual do Oeste do Paraná, Centro de Ciências Agrárias, Departamento de Zootecnia, \\ Marechal Cândido Rondon, Paraná, Brasil. \\ ${ }^{4}$ Emater, Marechal Cândido Rondon, Paraná, Brasil. \\ *Endereço para correspondência: marlibusanello@gmail.com
}

\section{SUMMARY}

The objective of the current work was to evaluate the use of oral probiotics comprised of viable and inactivated Lactobacillus spp. (referred to herein as "pool" of Lactobacillus spp.) on the performance, intestinal microbiota and blood parameters of piglets from birth to 35 days of age. Lactation piglets $(n=108)$, with an average initial weight of $1.41 \mathrm{~kg}$, and nursery piglets $(\mathrm{n}=72)$, with an average initial weight of $5.47 \mathrm{~kg}$, were included in the study and distributed in a randomized complete block design. The treatments were as follows: Control: $1 \mathrm{~mL}$ MRS broth $+1 \mathrm{~mL}$ sterile saline; Active: $1 \mathrm{~mL}$ probiotics ("pool" of Lactobacillus spp. and Lactobacillus plantarum) activated in MRS broth $+1 \mathrm{ml}$ saline; Inactive: 1 $\mathrm{mL}$ inactivated probiotics containing MRS broth + $1 \mathrm{~mL}$ saline. Treatments were not observed to affect total and daily weight gain of piglets during lactation. Differences were observed between treatments for feed intake, daily feed intake as well as total and daily weight gain from 21 to 35 days of age. Counts of lactic acid bacteria and coliforms were not affected by treatment or age. With the exception of globulin, blood parameters are also not affected. In the nursery phase the probiotic treatment with inactivated cells means a viable alternative for use primarily by the performance obtained for weight gain; however probiotics supplementation did not influence the microbiological counts and blood parameters.

Keywords: blood biochemistry, coliforms, lactobacilli, microorganisms, performance

\section{RESUMO}

Objetivou-se com este trabalho avaliar o uso oral de probióticos Lactobacillus spp viáveis e inativadas ("pool" de Lactobacillus spp.), sobre o desempenho, a microbiota intestinal, e parâmetros sanguíneos de leitões do nascimento aos 35 dias de idade. Foram utilizados na fase de aleitamento 108 leitões com peso médio inicial de $1,41 \mathrm{~kg}$ e, na creche, 72 leitões com peso médio inicial de $5,47 \mathrm{~kg}$, distribuídos em um delineamento experimental de blocos ao acaso. Os tratamentos foram: Controle: $1 \mathrm{~mL}$ de caldo MRS $+1 \mathrm{~mL}$ de solução salina estéril; Ativo: $1 \mathrm{~mL}$ de probiótico ("pool" de Lactobacillus spp. e Lactobacillus plantarum) ativados no caldo MRS $+1 \mathrm{~mL}$ de solução salina; Inativo: $1 \mathrm{~mL}$ de probiótico contendo células inativadas no caldo MRS $+1 \mathrm{~mL}$ de solução salina. Os tratamentos não influenciaram o ganho de peso total e diário dos leitões no aleitamento. Dos 21 aos 35 dias de idade, observou-se diferença entre os tratamentos para consumo de ração, consumo de ração diário, ganho de peso total e diário. As contagens de bactérias ácido-láticas e coliformes não foram influenciadas pelos tratamentos e idades. Com exceção da globulina, os demais parâmetros sanguíneos analisados não são influenciados. $\mathrm{Na}$ fase de creche o tratamento probiótico com células inativadas significa uma alternativa viável para uso principalmente pelo desempenho obtido para ganho de peso; no entanto os tratamentos probióticos não influenciam as contagens microbiológicas e os parâmetros sanguíneos.

Palavras-chave: bioquímica sanguínea, coliformes, desempenho, lactobacilos, microorganismos 
Rev. Bras. Saúde Prod. Anim., Salvador, v.16, n.2, p.387-396 abr./jun.., 2015 http://www.rbspa.ufba.br

\section{INTRODUCTION}

In order to protect suckling and weanling piglets from gastrointestinal disorders, growth-promoting antimicrobials have been used to help achieve the equilibrium of the intestinal flora of piglets. However, it is believed that indiscriminate use of antimicrobials in feed may result in bacterial resistance and residues in meat. In order to meet increasing consumer demands for safe and high quality foods, the probiotics (i.e. live microorganisms that, when administered in adequate amounts, confer health benefits to the host) have been reported as alternatives to antimicrobials (SAAD, 2006).

Probiotics used in swine farming can be viable or inactivated cells, and are typically composed of lactic bacteria, which are naturally found in the intestinal microbiota of piglets (RODRIGUES et al., 2007). However, it is important assessing if the viability of micro-organisms is an essential condition for the action that probiotics can have on the body, or if the inactivation process reduces or inhibits this action.

The current study sought to evaluate the use of oral probiotics comprised of viable and inactivated cells of gastrointestinal origin in pigs (referred to herein as "pool" of Lactobacillus spp. and Lactobacillus plantarum) on the performance, intestinal microbiota and blood parameters of piglets from birth to 35 days of age.

\section{MATERIAL AND METHODS}

The experiment was conducted in a Production Unit of Piglets with 730 sows, the farm being considered highhealth challenge, located in Nova Santa Rosa, west of the State of Paraná, Brazil. During the lactation phase were used 108 piglets from 18 sows of the Dalland line. The average birth weight of piglets was $1.41 \pm 0.22 \mathrm{~kg}$, being distributed in a randomized block design, with three treatments and six replicates, whose the criterion for the formation of the blocks was the initial weight. Each experimental unit was represented by a litter comprised of six piglets closer the mean, which were identified by marking the right ear.

At 21 days of age, the animals were transferred to the nursery, and used the same experiment design with the same three treatments and six repetitions, and, from that stage, four animals (two castrated males and two females) per experimental unit, totaling 72 piglets with an average initial weight of $5.47 \pm 0.87 \mathrm{~kg}$. Animals were housed in a brick shed (mansory barn) with concrete floors and ceramic tiles, endowed with suspended pens, semi-automatic feeders, sucking drinkers and wooden floor.

The treatments were as follows: Control: 1mL MRS broth (De Mann, Rogosa; Sharpe, 1960) $+1 \mathrm{~mL}$ sterile saline; Active: $1 \mathrm{~mL}$ probiotics $(8.60 \mathrm{x}$ $10^{7} \mathrm{CFU} / \mathrm{mL}$ "pool" of Lactobacillus spp. and Lactobacillus plantarum) activated in MRS broth $+1 \mathrm{~mL}$ saline; Inactive: $1 \mathrm{~mL}$ probiotics containing inactivated cells in MRS broth $+1 \mathrm{~mL}$ saline. Treatments were administered orally to the piglets daily in the morning from birth to 35 days of age, and $1 \mathrm{~mL}$ per piglet during the lactation phase as described by Correa et al. (2010) and $2 \mathrm{~mL}$ per piglet during nursery phase as described by Pieper et al. (2009).

Probiotics were prepared from active cultures referred to as L3, L4, L9 and L14, which were subjected to various compatibility tests, including resistance to hydrochloric acid, tolerance to bile salts and phenol, hydrophobicity and inhibition of Escherichia coli (MANGONI et al., 2011). Strains L3 and L14 were identified by the André Tosello Foundation (Campinas-SP) as 
Rev. Bras. Saúde Prod. Anim., Salvador, v.16, n.2, p.387-396 abr./jun.., 2015 http://www.rbspa.ufba.br ISSN 15199940

Lactobacillus plantarum. Probiotics were packaged in sterile containers and stored at $5^{\circ} \mathrm{C}$, being checked the cell viability by seeding in agar MRS during the period of seven days.

Inactivated probiotics were prepared according to the same methodology, but including an inactivation step that was performed using moist heat and sterilization at $121^{\circ} \mathrm{C}$ for 15 minutes. Seeding in MRS agar was performed to confirm inactivation.

The experimental diets (Table 1) were formulated to achieve the nutritional requirements proposed by Rostagno et al. (2011).

Table 1. Approximate composition of diets used for piglets from 10 to 21 and 21 to 35 days of age

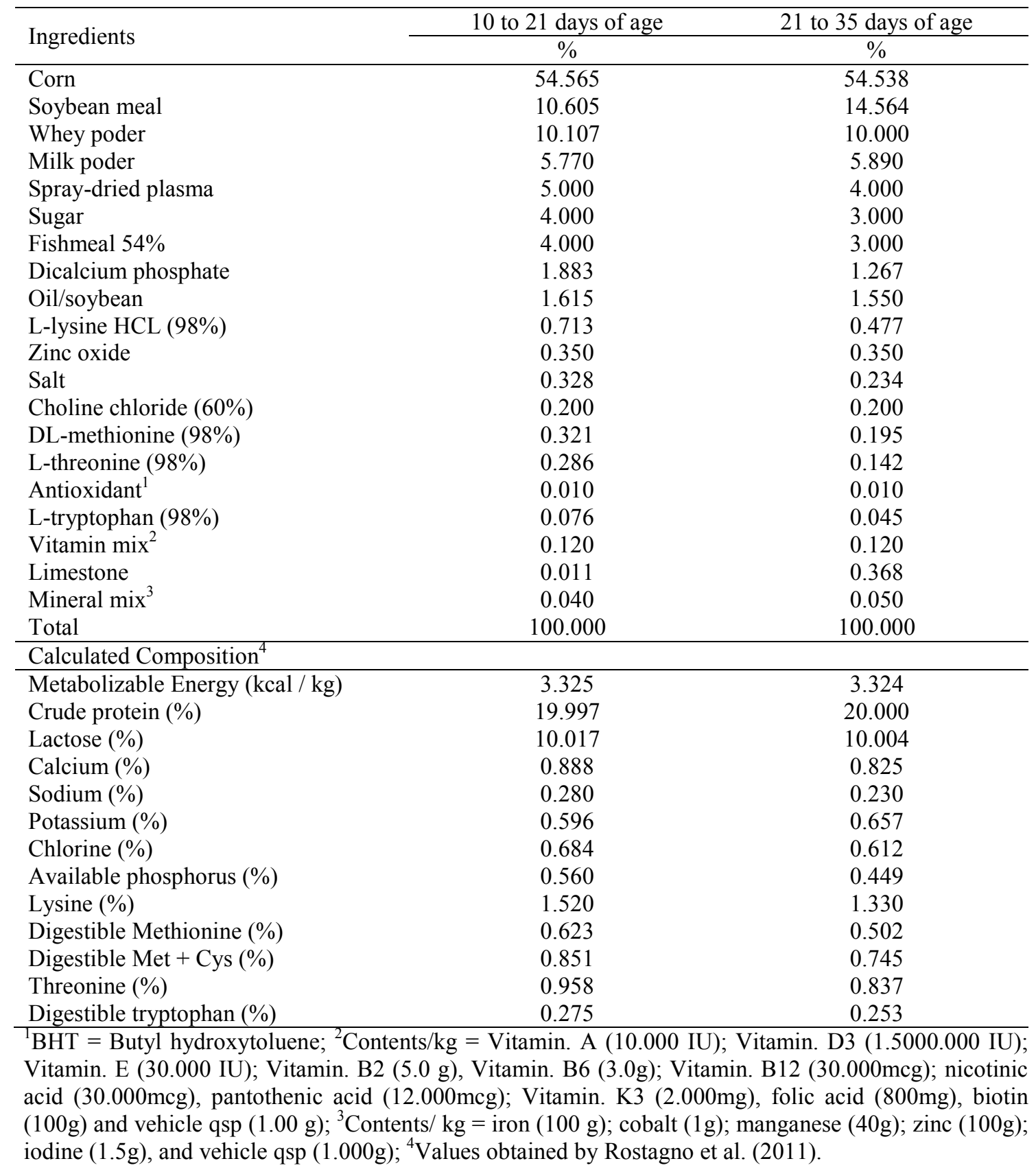


At 7, 21 and 35 days of age, fecal samples were collected from a piglet weighing closer to the mean of each experimental unit portion by massage of the terminal portion of the abdomen. The feces were collected directly from the rectum. After collection, kept into sterile bottles, the samples were transported to the Laboratory of Microbiology and Biochemistry UNIOESTE. For evaluation the acidlactic flora, the agar was used for Lactobacilli MRS, while the VRB (Violet Red Bile Agar) was used for coliforms, both incubated at $37^{\circ} \mathrm{C}$ for $48 \mathrm{hr}$.

From birth to 21 days of age, weight gain (WG) and daily weight gain (DWG) was monitored. From 21 to 35 days of age, DWG as well as daily feed intake (DFI) and feed conversion ratio (FCR) were evaluated. For monitoring the blood pattern and evaluating the immune system, blood samples were collected at 7,21 and 35 days of age from a piglet weighing closer to mean of each experimental unit.

Leukocytes (ul), lymphocytes (\%), eosinophils (\%), bats (\%), segmented $(\%)$, monocytes (\%) erythrocytes $(103 / \mu)$, hemoglobin $(\mathrm{g} / \mathrm{dL})$, hematocrit $(\%)$, and platelet count (ul) were determined using colorimetricimpedance-resistivity (i.e. physical and electronic measures). IgA quantifying was done using the nephelometry method. By the biuret method, total serum protein $(\mathrm{g} / \mathrm{dL})$ was measured, while albumin $(\mathrm{g} / \mathrm{dL})$ was quantified based on absorbance of bromocresol green.

The concentration of globulin $(\mathrm{g} / \mathrm{dL})$ was measured as previously described by Budiño et al. (2004) by the albumin subtraction from the total protein. Glucose (mg/dL) measurement was performed immediately after blood collection using an Accu-Chek Active blood glucose monitoring kit (Roche).

The experimental model used in the microbiological analysis and blood parameters was the split-plot with three treatments in the plots. Measurements over 7, 21 and 35 days of age are the subplots. Performance variables were evaluated by analysis of variance. Data were subjected to statistical analysis using the Statistical Analysis System (SAS, 2000) and Tukey's test. Statistical significance was defined as $\mathrm{P}<0.05$.

\section{RESULTS AND DISCUSSION}

No significant effect $(\mathrm{P}>0.05)$ of treatment on weight gain and daily weight gain of piglets from birth to 21 days of age was observed (Table 2), which is consistent with results reported by Gebert et al. (2011) similarly observed no difference in performance between their treatment groups of piglets given either supplemental milk or supplemental milk combined with Lactobacillus brevis.

Table 2. Performance of piglets in the control, the viable cell probiotics and the inactivated cell probiotics groups during suckling from birth to 21 days of age

\begin{tabular}{lcccc}
\hline \multirow{2}{*}{ Variable } & \multicolumn{3}{c}{ Treatments } & \multirow{2}{*}{ CV (\%) } \\
\cline { 2 - 4 } & Control & Active & Inactive & \\
\hline WG (kg) & 4.207 & 4.180 & 4.433 & 23.07 \\
DWG (g/day) & 200.39 & 199.00 & 211.10 & 23.08 \\
\hline
\end{tabular}

$\mathrm{WG}=$ weight gain; $\mathrm{DWG}=$ Daily weight gain.

No significant difference $(\mathrm{P}>0.05)$ was observed; $\mathrm{CV}=$ coefficient of variation. 
Although not observe significant difference in performance of piglets during suckling can be inferred that the administration of mainly probiotic inactive contributed to a better condition intestinal the colonization of beneficial lactic bacteria, which reflected positively $(\mathrm{P}<0.05)$ on the performance of piglets nursery phase.
In the nursery period from 21 to 35 days of age (Table 3), no significant difference was also observed $(\mathrm{P}>0.05)$ between the control and treatment groups with regards to average weight and feed conversion. However, differences were observed $(\mathrm{P}<0.05)$ between the treatments for feed intake, daily feed intake, weight gain and daily weight gain.

Table 3. Performance of piglets in the control, the viable cell probiotics and the inactivated cell probiotics groups during the nursery phase from 21 to 35 days of age

\begin{tabular}{lcccc}
\hline \multirow{2}{*}{ Variables } & \multicolumn{3}{c}{ Treatments } & \multirow{2}{*}{ CV $(\%)$} \\
\cline { 2 - 4 } & Control & Active & Inactive & \\
\hline IMW 21(kg) & 5.668 & 5.645 & 5.667 & 15.59 \\
FMW 35(kg) & 7.015 & 7.418 & 7.631 & 16.21 \\
FI (kg) & $2.218^{\mathrm{b}}$ & $2.745^{\mathrm{a}}$ & $2.750^{\mathrm{a}}$ & 9.05 \\
DFI (g/day) & $0.158^{\mathrm{b}}$ & $0.196^{\mathrm{a}}$ & $0.196^{\mathrm{a}}$ & 9.05 \\
WG (kg) & $1.399^{\mathrm{b}}$ & $1.772^{\mathrm{ab}}$ & $2.042^{\mathrm{a}}$ & 34.69 \\
DWG (g/day) & $99.96^{\mathrm{b}}$ & $128.58^{\mathrm{ab}}$ & $146.00^{\mathrm{a}}$ & 11.83 \\
FCR & 1.709 & 1.676 & 1.415 & 26.74 \\
\hline
\end{tabular}

$\mathrm{IMW}=$ initial mean weight; FMW $=$ final mean weight; FI $=$ feed intake; DFI $=$ daily feed intake; $\mathrm{WG}=$ weight gain; $\mathrm{DWG}=$ daily weight gain; $\mathrm{FCR}=$ feed conversion ratio.

*Values followed by different letters among treatments differed significantly $(\mathrm{P}<0.05)$ by Tukey's test at $5 \% ; \mathrm{CV}=$ coefficient of variation.

The post weaning period is characterized as a transition phase that presents various stressors, can be inferred that the piglets of the control treatment were more susceptive this period because had lower feed intake and lower daily feed intake $(\mathrm{P}<0.05)$ compared to both probiotic treatment groups. Furthermore, the Control group also had lower weight gain and daily weight gain compared to the probiotic treatment group with inactivated cells $(\mathrm{P}<0.05)$, but did not differ from the probiotic treatment group with viable cells.

Increased weight gain and daily weight gain in the probiotic treatment group with inactivated cells may be attributed to better absorption of nutrients in association with the balance of the intestinal microbiota due to probiotic effect and not just to diet intake, because all piglets received during suckling solid diet (control and probiotic) and this did not affect the performance at this phase; therefore the highest performance values in nursery phase for animals treated with probiotics it is due to probiotic effect, and not to simply intake of diet.

Regarding to the final weight, the results of this study agree with the study by Ross et al. (2010), who observed no significant difference in final weight of their treatment groups when they orally provided probiotics to piglets from 35 to 70 days of age. 
Rev. Bras. Saúde Prod. Anim., Salvador, v.16, n.2, p.387-396 abr./jun.., 2015 http://www.rbspa.ufba.br

Coliform counts and lactic acid bacteria were not affected $(\mathrm{P}>0.05)$ by either treatment. Moreover, no significant difference $(\mathrm{P}>0.05)$ between different collection days and treatments concerning to the number of colony forming units of lactic acid bacteria and coliforms (Table 4), can be inferred that, for this variable, the treatments resulted in the same effect

Table 4. Number of colony forming units (CFU/mL) of lactic acid bacteria and total coliform counts in feces of piglets in different treatment groups on the specified day of collection

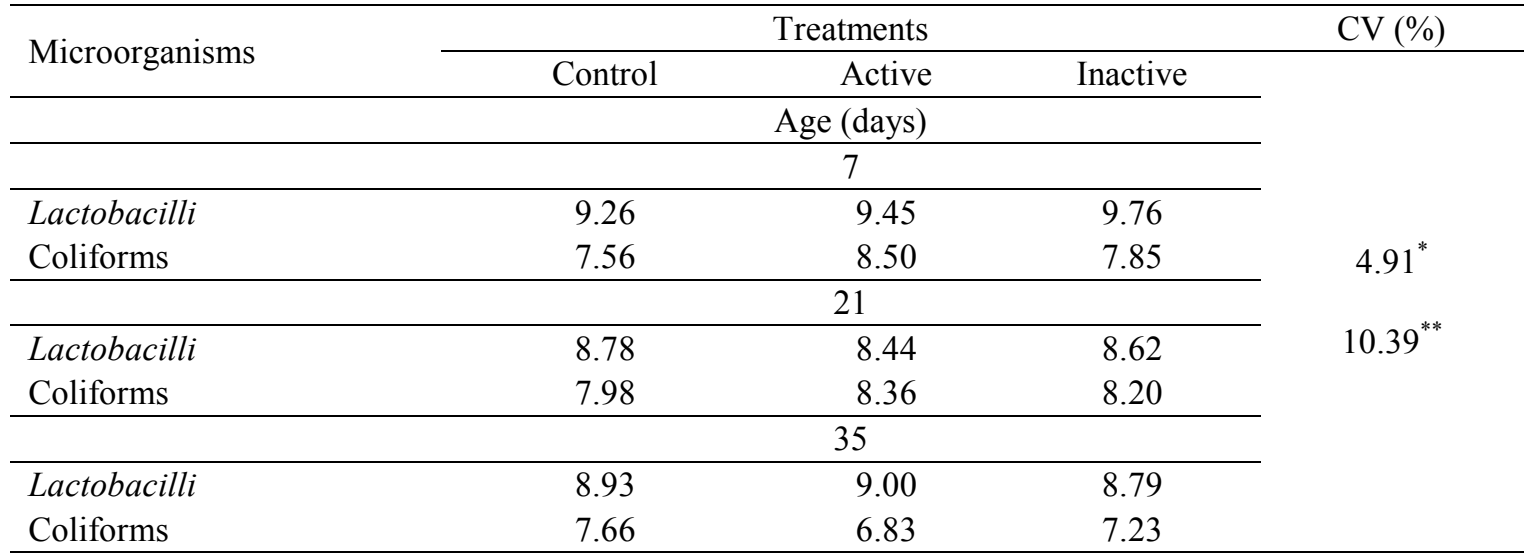

No significant difference $(\mathrm{P}>0.05)$ was observed; $\mathrm{CV}=$ coefficient of variation.

*Coefficient of variation for lactobacilli, ${ }^{* *}$ Coefficient of variation for coliforms.

These results are consistent with those reported by Correa et al. (2010) used oral probiotics composed of Lactobacillus reuteri and Bifidobacterium pseudolongum, and Gebert et al. (2011) which evaluated the use of Lactobacillus brevis probiotics. Both studies found that probiotic treatments had no effect on coliform counts in the duodenum, jejunum and ileum.

Similarly, no significant differences $(\mathrm{P}>0.05) \quad$ were observed among treatments in total serum protein, albumin or glucose concentration (Table 5).

Table 5. Concentrations of total serum protein, albumin, globulin and glucose in the blood of piglets in different treatment groups

\begin{tabular}{lcccc}
\hline Treatment & Total serum protein $(\mathrm{g} / \mathrm{dL})$ & Albumin $(\mathrm{g} / \mathrm{dL})$ & Globulin $(\mathrm{g} / \mathrm{dL})$ & Glucose $(\mathrm{mg} / \mathrm{dL})$ \\
\hline Control & 5.15 & 3.41 & $1.74^{\mathrm{a}}$ & 110.94 \\
Active & 4.79 & 3.40 & $1.39^{\mathrm{b}}$ & 113.72 \\
Inactive & 4.75 & 3.34 & $1.41^{\mathrm{b}}$ & 116.05 \\
\hline \multicolumn{5}{c}{ Period (days) } \\
\hline 7 & $5.96^{\mathrm{a}}$ & $2.62^{\mathrm{c}}$ & $3.33^{\mathrm{a}}$ & $121.77^{\mathrm{a}}$ \\
21 & $4.55^{\mathrm{b}}$ & $3.66^{\mathrm{b}}$ & $0.88^{\mathrm{b}}$ & $123.38^{\mathrm{a}}$ \\
35 & $4.18^{\mathrm{b}}$ & $3.86^{\mathrm{a}}$ & $0.31^{\mathrm{c}}$ & $95.55^{\mathrm{b}}$ \\
\hline $\mathrm{CV}(\%)$ & 9.22 & 6.52 & 30.19 & 10.93 \\
\hline
\end{tabular}

*Values followed by different letters between treatments and times differed significantly $(\mathrm{P}<0.05)$ by Tukey's test; $\mathrm{CV}=$ coefficient of variation. 
Rev. Bras. Saúde Prod. Anim., Salvador, v.16, n.2, p.387-396 abr./jun.., 2015 http://www.rbspa.ufba.br

The highest globulin concentration was observed in the control group. Concentrations of globulin may be increased when there was inflammatory or infectious diseases. Similar results for total serum protein, albumin and glucose were reported by Chiquieri et al. (2007). Significant differences $(\mathrm{P}<0.05)$ for all variables were observed between samples collected at 7,21 and 35 days of age.

Regardless of treatment, total serum protein was higher at 7 days $(\mathrm{P}<0.05)$ compared to 21 and 35 days of age, not differing from 21 to 35 days of age $(\mathrm{P}>0.05)$. Reduction in the levels of total serum protein was likely due to low feed intake by piglets during postweaning, thus causing a decrease in their protein reserves (BUDIÑO et al., 2004). For albumin, lowest levels $(\mathrm{P}<0.05)$ were detected at 7 days of age, but subsequently increased $(\mathrm{P}<0.05)$ at 21 and 35 days of age. Increased plasma albumin may occurs as a result of dehydration or excessive loss of fluids, the fact observed in this study. Globulin concentration was highest $(\mathrm{P}<0.05)$ at 7 days and decreasing by 21 and 35 days of age. Globulins may be decreased in immunodeficiencies associated with deficiencies in B lymphocytes (TIZARD, 2009).

In this paper, there was decrease in glucose levels $(\mathrm{P}<0.05)$ at 35 days of age compared to 7 and 21 days of age; however, they presented normal when compared to the reference values (KANEKO, 1997). The daily management for oral administration of treatments may have influenced the level of stress in piglets, once it increases the glucose levels. Therefore, higher rates of glucose until age 21 days and this value decreases as the vain animals adapting to management at age 35 days obtained the lowest value.

No differences $(\mathrm{P}>0.05)$ were observed for any variables between the treatment groups (Table 6). These results corroborate the studies by Névoa et al. (2013).

Table 6. Hemogram of piglets based on treatment and day of blood collection

\begin{tabular}{|c|c|c|c|c|c|c|c|c|c|c|}
\hline Treatment & $\begin{array}{c}\mathrm{Hb} \\
(\mathrm{g} / \mathrm{d})\end{array}$ & $\begin{array}{c}\text { Le } \\
(\mu \mathrm{L})\end{array}$ & $\begin{array}{l}\mathrm{Ht} \\
(\%) \\
\end{array}$ & $\mathrm{He}\left(10^{3} /\right)$ & $\begin{array}{l}\text { Eos } \\
(\%) \\
\end{array}$ & $\begin{array}{l}\text { Bast } \\
(\%)\end{array}$ & $\begin{array}{l}\text { Seg } \\
(\%) \\
\end{array}$ & $\begin{array}{c}\text { Linf } \\
(\%)\end{array}$ & $\begin{array}{c}\text { Mon } \\
(\%) \\
\end{array}$ & $\begin{array}{l}\text { Plat } \\
(\mu \mathrm{L})\end{array}$ \\
\hline Control & 10.74 & 16.48 & 40.14 & 5.55 & 0.77 & 1.61 & 47.44 & 42.94 & 3.44 & 491.67 \\
\hline Active & 10.45 & 16.03 & 40.98 & 5.37 & 0.66 & 1.33 & 42.94 & 31.22 & 2.55 & 505.94 \\
\hline Inactive & 9.95 & 17.02 & 39.42 & 5.02 & 1.00 & 3.05 & 50.88 & 42.33 & 3.11 & 487.50 \\
\hline \multicolumn{11}{|c|}{ Period (days) } \\
\hline 7 & $8.72^{b}$ & $12.8^{b}$ & $31.8^{\mathrm{b}}$ & $6.22^{\mathrm{a}}$ & $0.61^{\mathrm{a}}$ & $3.22^{\mathrm{a}}$ & $55.50^{\mathrm{a}}$ & $36.77^{\mathrm{a}}$ & $3.66^{\mathrm{a}}$ & $509.06^{\mathrm{a}}$ \\
\hline 21 & $11.27^{\mathrm{a}}$ & $11.52^{b}$ & $46.17^{\mathrm{a}}$ & $5.71^{\mathrm{b}}$ & $0.55^{\mathrm{a}}$ & $0.55^{\mathrm{b}}$ & $37.44^{\mathrm{b}}$ & $36.00^{\mathrm{a}}$ & $3.22^{\mathrm{a}}$ & $487.78^{\mathrm{a}}$ \\
\hline 35 & $11.14^{\mathrm{a}}$ & $25.20^{\mathrm{a}}$ & $42.51^{\mathrm{a}}$ & $4.02^{c}$ & $1.27^{\mathrm{a}}$ & $2.22^{\mathrm{ab}}$ & $48.33^{\mathrm{ab}}$ & $43.72^{\mathrm{a}}$ & $2.22^{\mathrm{a}}$ & $488.28^{\mathrm{a}}$ \\
\hline $\mathrm{CV}^{1}$ & 6.47 & 25.09 & 14.25 & 6.95 & 29.35 & 35.81 & 36.40 & 42.43 & 25.68 & 35.28 \\
\hline
\end{tabular}

According to Feldman et al. (2000), the primary function of eosinophils is to combat toxic substances and, therefore, they will be present in lesser amount in the bloodstream in stressful situations elucidating the lowest value observed 
Rev. Bras. Saúde Prod. Anim., Salvador, v.16, n.2, p.387-396 abr./jun.., 2015 http://www.rbspa.ufba.br

on piglets aged 21 days, reappearing later these situations justifying the high number eosinophil at age 35 days.

With age, an increase $(\mathrm{P}<0.05)$ in the amount of leukocytes was observed at 35 days of age. According to Feldman et al. (2000), the adrenaline released in response to stress or agitation moves marginal leukocytes into the circulation, resulting in an increase in total leukocyte count when an animal is stressed, which may explain the observed increase after weaning.

The percentage of bats and segmented was lower $(\mathrm{P}<0.05)$ at day 7 compared to day 21. Differences $(\mathrm{P}<0.05)$ in hemoglobin and hematocrit levels were observed on day 7 compared to 21 and 35 days of age. Such differences in the levels of hemoglobin and hematocrit may be due to iron deficiency in piglets. Since iron present in colostrum is sufficient to supply about 10 to $20 \%$ of requirements, with the remainder removed the reserves of the organism (OLIVEIRA \& BARCELLOS, 2012)

Erythrocytes decreased $(\mathrm{P}<0.05)$ with age. The decline in the number of erythrocytes in the first week of life is related to the rapid plasma volume expansion induced by the colostrums consumption, fetal erythrocytes destruction and insufficient iron supply for the hemoglobin synthesis (JAIN, 1993).

No differences $(\mathrm{P}>0.05)$ in serum levels of $\operatorname{IgA}$ were observed between treatment groups (Table 7). While assessing the use of probiotics containing inactivated Lactobacillus acidophilus versus probiotics with viable Lactobacillus acidophilus, Bifidobacterium bifidum and Enterococcus faecium in piglets from birth to 30 days of age, Rodrigues et al. (2007) reported that IgA serum levels were higher in the probiotic group with viable cells than in the control and probiotic treatment group with inactivated cells.

Table 7. IgA serum levels in piglets based on treatment and day of collection

\begin{tabular}{lc}
\hline Treatment & IgA $(\mathrm{mg} / \mathrm{dL})$ \\
\hline Control & 27.79 \\
Active & 26.08 \\
Inactive & 28.49 \\
\hline \multicolumn{2}{c}{ Period (days) } \\
\hline 7 & $37.94^{\mathrm{a}}$ \\
21 & $41.62^{\mathrm{b}}$ \\
35 & $2.79^{\mathrm{c}}$ \\
\hline $\mathrm{CV}(\%)$ & 15.94 \\
\hline *Values followed by different letters between \\
treatments and periods differed significantly \\
(P<0.05) by a Tukey's test; CV= coefficient of \\
variation.
\end{tabular}

Levels of $\operatorname{IgA}$ increased from 7 to 21 days, which may be related to the fact that the $\operatorname{IgA}$ is the most resistant immunoglobulin to intestinal degradation. A decrease in IgA serum levels from 21 to 35 days of age is consistent with the study by Almeida et al. (2007), who reported that weaning leads to decreased immunoglobulin production, possibly due to the stress associated to this period.

Decreased IgA levels after weaning were also demonstrated by Lessard et al. (2009), who assessed administration of probiotics containing Pediococcus acidilactici and Saccharomyces cerevisiae boulardii, or both, during lactation and added to ration when weaning, observed reduction in IgA levels in the ileum in all groups after weaning.

In the nursery phase the probiotic treatment with inactivated cells means a viable alternative for use primarily by the performance obtained for weight gain; however probiotics supplementation did not influence the microbiological counts and blood parameters. 
Rev. Bras. Saúde Prod. Anim., Salvador, v.16, n.2, p.387-396 abr./jun.., 2015 http://www.rbspa.ufba.br ISSN 15199940

\section{REFERENCES}

ALMEIDA, R.F.; LOPES, E.L.; NUNES, R.C.; MATOS, M.P.C.; FIORAVANTI, M.C.S.; SOBESTIANSKY, J.; BRITO, L.A.B.; RUFINO, L.M. Ferro e imunidade humoral em suínos alimentados com fitase e níveis reduzidos de fósforo. Ciência Animal Brasileira, v.8, n.4, p.767-776, 2007.

BUDIÑO, F.E.L; THOMAZ, M.C; KRONKA, R.N.; PIZAURO JÚNIOR, J.M.; SANTANA, Á.E.; TUCCI, F.M.; FRAGA, A.L.; SCANDOLERA, A.J.; HUAYNATE, R.A.R. Influência da adição de probiótico e/ou prebiótico em dietas de leitões desmamados sobre as atividades das enzimas digestivas e parâmetros sangüíneos. Acta Scientiarum. Animal Sciences, v.26, n.4, p.529-536, 2004.

CORREA, V.S.; CARAMORI JUNIOR, J.G.; VIEITES, F.M.; ABREU, J.G. de.; BARROS, D.S. Probiótico líquido para leitões lactentes em diferentes idades.

Revista Brasileira de Saúde e Produção Animal [online], v.11, n.3, p.827-837, 2010.

CHIQUIERI, J.; NERY, H.V.L.; SOARES, R. da T.R.N.; CARVALHO, E.C.Q. de.; COSTA, A.P.D. da. Bioquímica sanguínea e altura das vilosidades intestinais de suínos alimentados com adição de probiótico, prebiótico e antibiótico. Revista Brasileira de Saúde e Produção Animal [online], v.8, n.2, p.97-104, 2007.

FELDMAN, B.F.; ZINKL, J.G.; JAIN, N.C. Schalm's Veterinary

Hematology. 5th ed. Philadelphia: Lippincott Williams and Wilkins, 2000. $787 \mathrm{p}$.
GEBERT, S.; DAVIS, E.; REHBERGER, T.; MAXWELL, C.V. Lactobacillus brevis strain 1E1 administered to piglets through milk supplementation prior to weaning maintains intestinal integrity after the weaning event. Beneficial Microbes, v.2, n.1, p.35-45, 2011.

JAIN, N.C. Essentials of Vetrerinary Hematology. Philadelphia: Lea \& Febiger, 1993. p.19-53.

KANEKO, J.J.; HARVEY, J.; BRUSS, M. Clinical biochemistry of domestic animals. 5th ed. San Diego: Academic Press, 1997. 932 p.

LESSARD, M.; DUPUIS, M.; GAGNON, N.; NADEAU, E.; MATTE, J.J.; GOULET, J.; FAIRBROTHER, J.M. Administration of Pediococcus acidilactici or Saccharomyces cerevisiae boulardii modulates development of porcine mucosal immunity and reduces intestinal bacterial translocation after Escherichia coli challenge. Journal of Animal Science, v.87, n.3, p.922-934, 2009.

MANGONI, J.; POZZA, M.S.S.; SABEDOT, M.A.; POZZA, P.C.; ALMEIDA, S. de.; HEINZEN, E.L. Potencial probiótico de lactobacilos de origem suína. Acta Scientiarum. Animal Sciences, v.33, n.3, p.267-272, 2011.

NÉVOA, M.L.; CARAMORI JÚNIOR, J.G.; CORRÊA, G.S.S.; ARANTES, V.M.; KAMIMURA, R.; GONÇALVES, F.C.; OLIVEIRA, M.S.F.; SANTOS, A.L.; NALON, R.P. Desempenho e características bioquímicas de leitões submetidos a dietas com aditivos probióticos, prebióticos, simbióticos e antibióticos. Arquivo Brasileiro de Medicina Veterinária e Zootecnia, v. 65, n.2, p.447-454, 2013. 
Rev. Bras. Saúde Prod. Anim., Salvador, v.16, n.2, p.387-396 abr./jun.., 2015 http://www.rbspa.ufba.br

OLIVEIRA, S.J.; BARCELLOS, D.

Anemia ferropriva. In:

SOBESTIANSKY, J.; BARCELLOS D.

Doenças dos Suínos. 2ed. Goiânia:

Canône Editorial. 2012. p.719-722.

PIEPER, R.; JANCZYK, P.;

URUBSCHUROV, V.; KORN, K.;

PIEPER, B.; SOUFFRANT. W.B. Effect

of a single oral administration of

Lactobacillus plantarum DSMZ

$8862 / 8866$ before and at the time point

of weaning on intestinal microbial

communities in piglets. International

Journal of Food Microbiology, v.130, n.3, p.227-232, 2009.

ROSS, G.R.; GUSILS, C.;

OLISZEWSKI, R.; HOLGADO, S.C.

de.; GONZÁLEZ, S.N. Effects of

probiotic in swine. Journal of

Bioscience and Bioengineering, v.109, n.6, p.545-549, 2010.

RODRIGUES, M.A.M.; SILVA, D.A.O.; TAKETOMI, E.A.;

BLAZQUEZ- HERNANDEZ., F.J. IgA production, coliforms analysis and intestinal mucosa morphology of piglets that received probiotics with viable or inactivated cells. Pesquisa Veterinária Brasileira, v.27, n.6, p.241-245, 2007.

ROSTAGNO, H.S.; ALBINO, L.F.T.;

DONZELE, J.L.; GOMES, P.C.,

OLIVEIRA, R.F., LOPES, D.C.,

FERREIRA, A.S.; BARRETO, S.L.T.;

EUCLIDES, R.F. Tabelas brasileiras

para aves e suínos: composição de alimentos e exigências nutricionais. 3.ed.Viçosa: UFV, 2011.

SAAD, S.M.I. Probióticos e prebióticos: o estado da arte. Revista Brasileira de Ciências Farmacêuticas, v.42, n.1, p.116, 2006.
STATISCAL ANALYSES SYSTEM SAS. SAS/STAT User's guide. Version 8.2. 4.ed. Cary: SAS Institute. 2000.

TIZARD, I.R. Imunologia Veterinária. 8th ed. São Paulo: Saunders Elsevier, v.34, p.462-466, 2009.

Data de recebimento: 09/04/2014

Data de aprovação: 17/06/2015 